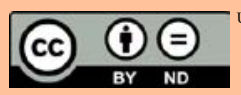

Załącznik Kulturoznawczy 3/2016

FOTOESEJ I OKOLICE

\section{„MYŚLĘ, ŻE UMRĘ”}

\section{MAGDALENA SZCZYPIORSKA-MUTOR}

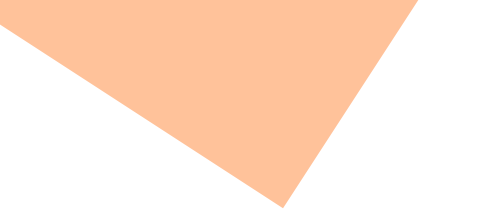

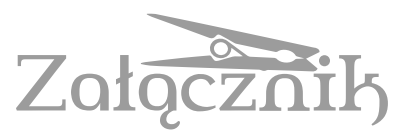

Wydział Polonistyki Uniwersytetu Warszawskiego

Faculty of Polish Studies University of Warsaw (Poland)

magda.szczypiorska.mutor@gmail.com

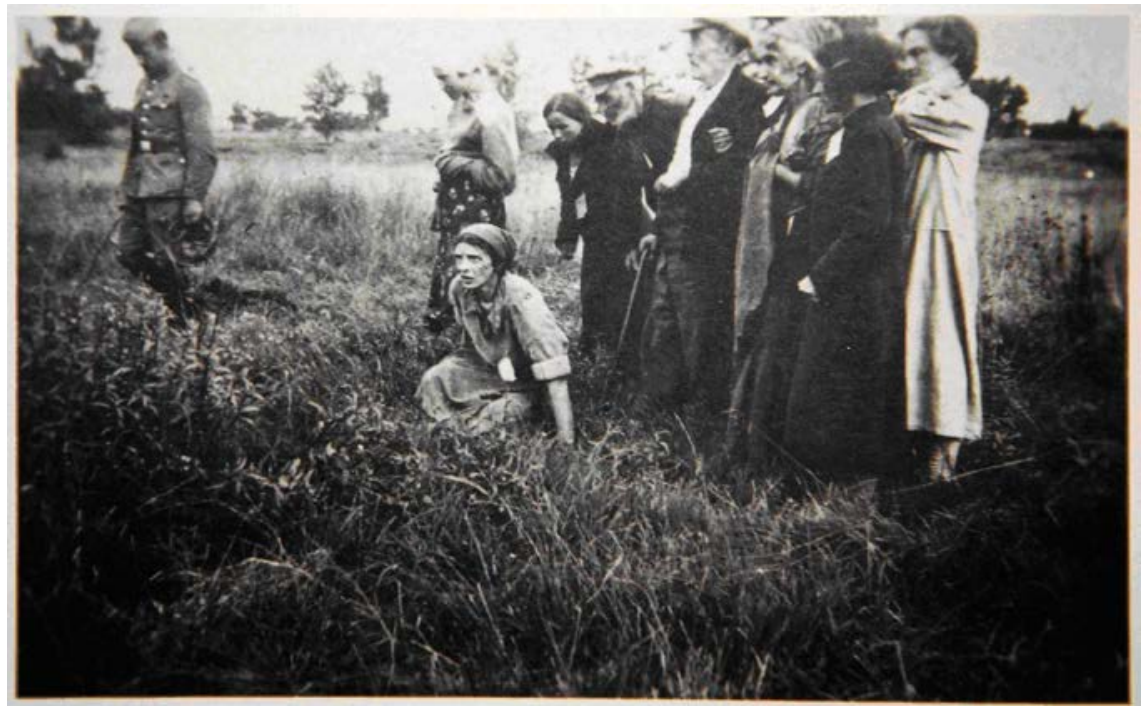

Il. 1. fot. nieznany

1.

Pierwsze zdjęcie - słoneczny październikowy dzień. Drzewa na horyzoncie, niewyraźne, rozmyte. Łąka - bujna, gęsta, niekoszona; osty, różne gatunki

1 Zdjęcie publikowane dzięki uprzejmości TAiWPN Universitas za: I. Jeffrey, Jak czytać fotografię. Lekcje mistrzów fotografii, tłum. J. Jedliński, Kraków 2009, s. 250. 
traw. Pewnie jeszcze ciepła, jeszcze nagrzana słońcem, mimo października jeszcze żywa. Może jeszcze pachnie, jak pachną łąki późnym latem; może jeszcze jakieś brzęczące życie toczy się wśród drobnych liści. Może dałoby się schować w tych wysokich trawach, przycupnąć w miękkich źdźbłach, kiedy tak trudno utrzymać się na nogach. Dotknąć ręką twardego gruntu, upewnić się, że jest. Ale jaki jest, jaka jest w dotyku ta ziemia, to dno październikowej łąki - jeszcze miękka, wilgotna, czy już przerośnięta korzeniami perzu, sucha, jesienna? Twarda czy sypka?

Czy łatwo wykopać w takiej ziemi dół? I co widać pod dnem łąki? Warstwa czarnej ziemi, gliniaste błoto, kamienie, piach. Mysie nory, krecie arterie. Białe nici łąkowych grzybni, gniazda chrząszczy grabarzy, splątane korzenie. Chłód.

Jak duży powinien być dół, żeby zmieścić w nim ośmioro ludzi?

\section{2.}

Ręka na środku kadru dotyka ziemi, szuka oparcia. Inne ręce wędrują w poszukiwaniu ciepła, śladów życia, bliskości skóry - jedna zwinięta w pięść, inna schowana pod chustą, w kieszeni, w fałdach swetra, wtulona pod ramię tego, kto stoi obok, ułożona na szyi, w miejscu, gdzie czuje się pulsowanie krwi. Delikatne gesty, które upewniają, że serce bije, że skóra na brzuchu jeszcze jest ciepła i miękka, podszewka w kieszeni tak dobrze znajoma, a rączka drewnianej laski nadal daje solidne oparcie. Już nic innego nie można zrobić, już tylko dłoniom wolno uprawiać te małe, prawie niezauważalne wędrówki.

Już nic nie można zrobić - można tylko czekać: więc stoją, siedmioro po prawej stronie kadru i ona, na środku, na trawie, jakby osunęła się na ziemię.

„Żydzi tuż przed rozstrzelaniem”. Tuż przed? Co to znaczy „tuż przed”? Sekundy? Trzy minuty? Dwadzieścia oddechów dziewczyny, która trzyma rękę na brzuchu, pięćdziesiąt uderzeń tętna kobiety z dłonią na szyi?

Co jeszcze trzeba zrobić - ustawić ich w równym szeregu? Zlecić wykopanie dołu? Pozwolić im odejść i zabawić się serią w plecy? Urozmaicić ten ochłap czasu jakimś innym wyrafinowanym żartem?

Jak długo już czekają? Jak czekają? Nie wierzą w śmierć, nikt nie wierzy, ale na wszelki wypadek lepiej znieruchomieć i nie podnosić oczu. Więc stoją, zastygli, żeby nie dotknąć, nie rozkołysać tej niewyobrażalnej rozpaczy, tego instynktu, który każe krzyczeć i uciekać - bo wtedy już wszystko 
będzie stracone. A tak, może się uda, może się rozmyślą, może coś, ktoś, w ostatniej chwili... Zastygnąć, żeby zbyt wiele nie czuć - a jeśli już, to tylko ten pulsujący kawałek skóry, tylko ciepło cienkiej wełenki płaszcza, żywą miękkość włosów.

Czekają, jeszcze po stronie życia, po stronie powietrza, ale już zmartwiali, już martwi w swoim znieruchomieniu. Ona, kobieta, która przykucnęła w trawie, czeka już po stronie śmierci, po stronie ziemi, ale jeszcze żywa w geście szaleństwa, wyłamania się z bezruchu tamtych. Już umierająca, choć jeszcze nie padł strzał. Już opada na dno, zapada się pod ziemię. Najbardziej żywa na zdjęciu i najbardziej umarła.

Jej twarz: zadrapanie na policzku, kosmyk włosów spod chustki. Jej twarz: pieprzyk nad prawą brwią. Jej twarz: usta, oczy, spojrzenie. Jej spojrzenie: nie ma słów.

3.

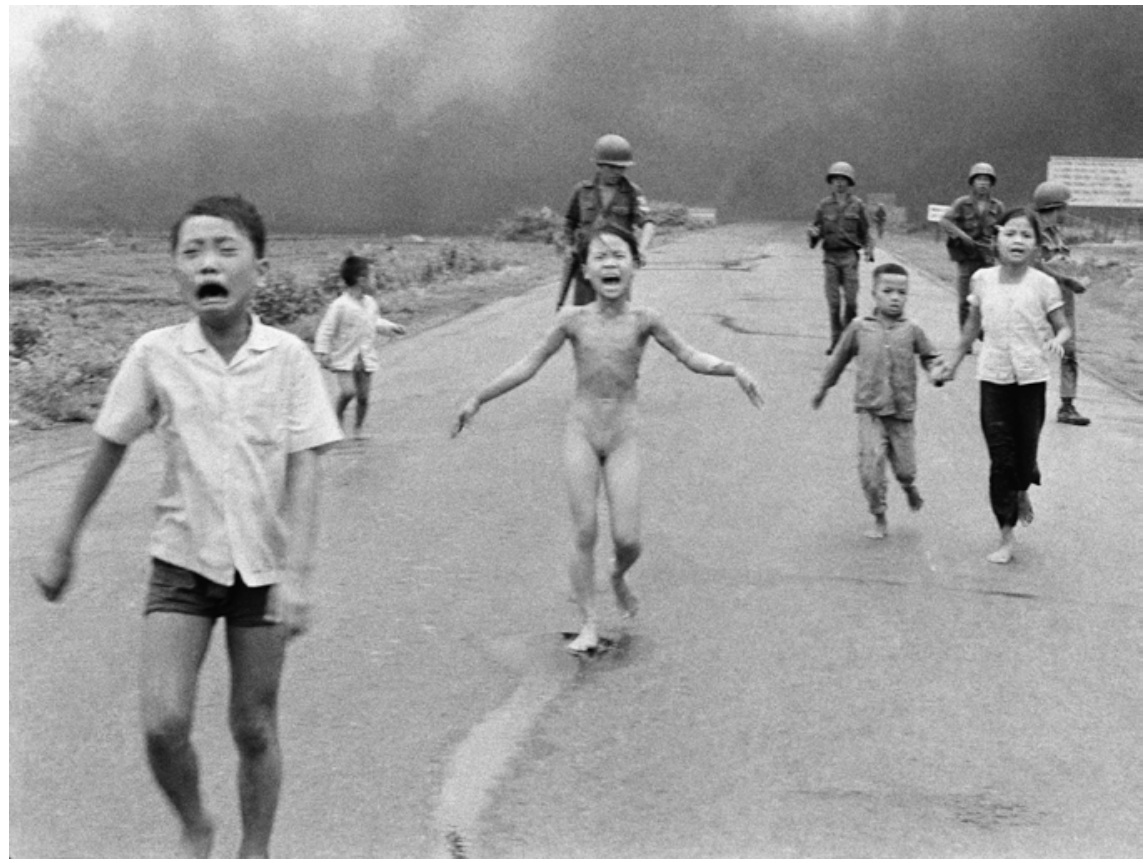

Il. 2. fot. Nick Ut (Ap Images/EastNews) 
Drugie zdjęcie - czarny dym na horyzoncie. Droga, hełmy żołnierzy, płonące dzieci. Napalm pali. Skórę, włosy, paznokcie, kości. Dzieci biegną, uciekają, bose nogi, palący asfalt, szybciej, szybciej - zrzucić ubranie, zrzucić skórę. Dwójka z lewej: najmłodszy chłopczyk w półobrocie w stronę ściany dymu, rozdarta szlochem twarz starszego. Dwójka z prawej: dziewczynka, która nie ma siły dalej biec, i mały chłopiec - przynajmniej on ma kogo trzymać za rękę. Na środku ona - naga dziewięciolatka, nieopierzony pisklak, ręce jak przetrącone skrzydełka, jak obluzowane ramiona lalki, płaty jasnej, spalonej skóry. Biegnie. Między krzykiem a krzykiem, zanim złapie nowy haust parzącego powietrza, powtarza: „Nong qua! Nong qua!” - „Za gorąco! Za gorąco!".

Gdzieś w górze, w dymie, poza kadrem, warczą silniki samolotów. Jeden z nich kilka sekund wcześniej zrzucił na drogę bomby z napalmem - tam, skąd teraz naciera dym. Pilot się pomylił - myślał, że to partyzanci.

4.

$\mathrm{Na}$ kolejnej klatce tego samego filmu dziewczynka stoi tyłem w rozpryskanej mokrej plamie - przed chwilą jeden z dziennikarzy polewał ją wodą. Drobna dziewuszka $\mathrm{z}$ warkoczykiem: można by wyobrazić sobie, że tapla się w kałuży w upalny dzień, gdyby nie żołnierze wokół, gdyby nie kamery i mikrofony, gdyby nie dym. Gdyby nie plecy - z których spalona skóra schodzi jak łuszcząca się farba. Za chwilę Nick Ut, autor zdjęcia, wietnamski fotograf pracujący dla Associated Press, zawiezie wszystkie poparzone dzieci do szpitala i dopilnuje, żeby mała miała dobrą opiekę. Zanim fotograf weźmie dziewczynkę na ręce i ostrożnie wniesie ją do swojego samochodu, dziewięciolatka powie do brata (pierwszego z lewej strony kadru): „Myślę, że umrę".

Dziewczynka ma na imię Kim Phúc. Nick Ut sfotografował ją 8 czerwca 1972 roku w okolicach wioski Trang Bang, przy autostradzie prowadzącej z Sajgonu do granicy z Kambodżą ${ }^{2}$.

${ }^{2}$ Niektóre szczegóły historii Kim Phuc podaję za: K. Dąbrowski, Napalm i dziewczynka, „Przekrój”, nr 12(3326) z 26 marca 2009 r., s. 75. 
5.

Pierwsze zdjęcie nie ma swojej następnej klatki. Gdyby była, gdyby wyobrazić sobie możliwe wersje kolejnego kadru - różniłyby się tylko rytmem padających strzałów, układem padających ciał. Kobieta na trawie nie ma imienia. Jej podpis to żółta łata na ubraniu. Fotograf jest nieznany. Jego podpis: „Juden kurz vor der Erschiessung”. Okolice Kijowa, październik 1941. Czas:

Pierwsze zdjęcie - między życiem a śmiercią.

Drugie - od śmierci do życia.

Miejsce:

Pierwsze zdjęcie - między powietrzem a ziemią.

Drugie - między ogniem a wodą.

\section{6.}

Pierwsze zdjęcie - strzęp przestrzeni, strzęp czasu, płatek popiołu. Sfotografowani w ostatniej chwili, wyrwani ziemi w ostatnim mgnieniu. Siedem twarzy złapanych w nieostrości, profile rysowane rozmytą kreską. I ta jedna pośrodku, jednocześnie ostra i niewidzialna - jak ją zobaczyć, kiedy tak trudno na nią spojrzeć, tak trudno odpowiedzieć na jej spojrzenie? Można powoli oswajać kadr. Można próbować i próbować - jeszcze jedno, kolejne spojrzenie na zdjęcie. I znowu jest tak samo: oczy wędrują po elipsie, która wyznacza granicę ostrości, wzrok zatacza kręgi, na ułamek sekundy ześlizguje się na środek kadru, na jej twarz - zerknąć, ale nie zobaczyć, spojrzeć, ale nie widzieć. Bezpieczne obrzeża zdjęcia: łąka - czy ta kępa z lewej to lwie paszcze? A ta ciemna plama $\mathrm{z}$ prawej to cień korony drzewa spoza kadru? Może chmura? A drzewa na horyzoncie - co to za drzewa? Kudłaty pies przy nodze żołnierza jest już niebezpiecznie blisko twarzy kobiety, więc szybko w górę: guziki munduru, klamra pasa, a w lewej ręce? Hełm? Kask motocyklowy? Absurd rozważania takich szczegółów kieruje wzrok na drugą stronę zdjęcia (żeby bezpiecznie ominąć centrum kadru, trzeba przenieść spojrzenie górą, na moment odrywając wzrok). Z prawej: oni, ci stojący, nieistotne detale - grzebień we włosach, opadające fałdy ciepłych pończoch, pogniecione spodnie.

Za jasnym płaszczem pierwszej kobiety z prawej wzrok znajduje chwilę wytchnienia, bezpieczną kryjówkę, daleko od niej, daleko od jej spojrzenia - wąski pasek kadru, gdzie oczy mogą odpocząć. Schować się za ich 
plecami, daleko od niej, daleko od tych, na których ona patrzy. Dwie białe kropeczki - jedna z nich to skaza negatywu, więc odwraca uwagę w stronę technicznego procesu, losów odbitki, pomaga wycofać się z kadru, uciec z tego październikowego słońca.

\section{7.}

Twarz dziewczynki z drugiego zdjęcia szybciej daje się oswoić, gładko poddaje się oczom. Łatwiej zamienia się w papier, w zdjęcie, które można ugłaskać spojrzeniem, uspokoić. Można patrzeć, polerować wzrokiem bolesne zadry, raniące kanty, aż się wygładzi, zmatowieje, uciszy. Wtedy można zdjęcia dotknąć, owinąć słowami. Poruszające - tak; szokujące - tak; rozdzierające - tak; straszne - tak, tak, tak. Pomaga kontekst - dziewczynka biegnie w stronę ratunku, w stronę wody, w stronę fotografa, który za chwile ocali jej życie. To uspokaja widza, nie wciąga $w$ kadr, nie rzuca na asfalt drogi między ryżowe pola, $w$ ten lepki popiół dymu, $w$ to spalone powietrze, w wysoki, szklany pisk: „Nong qua!”. Nie wymaga interwencji. W jakiś sposób usprawiedliwia wulgarny komfort przyglądania się krzyczącym z bólu dzieciom z perspektywy własnego fotela. Zapach napalmu („Nic na świecie tak nie pachnie - twierdził podpułkownik Kilgore w Czasie Apokalipsy Uwielbiam zapach napalmu o poranku"), strzępy spalonej skóry i krzyk zostają tam, w kadrze.

To jedno ze zdjęć, które uświadamiają, jak bardzo patrzymy na obraz nie tylko oczami fotografa - patrzymy z wnętrza jego skóry, identyfikując się z nim. A także: $\mathrm{z}$ tym, co zrobi w chwilę potem, tuż po. Ósmego czerwca 1972 roku dziewczynka biegła w stronę Nicka Uta. Na zdjęciu biegnie, wciąż i wciąż, w stronę tego, kto patrzy. Uff... - oddychamy z ulgą, śledząc ślady bosych nóżek na asfalcie - biegnie do dorosłego, który pomoże, który zachowa się przyzwoicie. Ten kojący porządek świata, ruch od cierpienia do ratunku, od ognia do wody, przez chwilę pozwala nie pamiętać o tym, że zanim Nick Ut wcisnął migawkę aparatu, kilka minut wcześniej ktoś inny wcisnął guzik otwierający ładownię pełną bomb.

Jeszcze inną perspektywę odbioru tego zdjęcia zarysowuje dokumentalny film kręcony między jedną a drugą migawką Nicka Uta. Na filmie widać biegnące dzieci, zmęczone, zszokowane, jakby zdziwione - w kolorze i ruchu wygląda to mniej dramatycznie niż na czarno-białym zdjęciu. Już po pierwszym obejrzeniu filmu z kilkuminutowej sekwencji zostaje w pamięci jedna 
scena, jeden drobny gest żołnierza albo dziennikarza, który poi dziecko wodą z manierki - ułożenie jego dłoni, sposób, w jaki podtrzymuje trzęsącą się bródkę dziewczynki, żeby mogła wypić jeszcze jeden łyk.

Ten wzruszający, ledwo uchwytny gest na chwilę pozwala zapomnieć o pytaniu, dlaczego dzieci musiały biec tak długo, mijając żołnierzy, mijając kamerzystę, który zignorował je, kiedy przebiegały obok, kiedy, machając rękami, bezradnie próbowały mu coś powiedzieć, coś wypiszczeć, wytłumaczyć. Albo ta scena: kamerzyści filmują kobietę słaniającą się na nogach, dźwigającą nieprzytomne dziecko, z którego zwisają płaty spalonej skóry. Ona drepcze z wyraźnym wysiłkiem, oni filmują, dziecko wyślizguje się, oni kadrują, ona poprawia ciężar, oni dopracowują zbliżenie. Ona żali się, płacze i drepcze dalej. Oni filmują. „Jestem kamerzystą” - pisał Douglas Dunn:

Cierpią, a ja chwytam tylko naskórek.

Reszta jest niewyrażalna, poza

Tym, co da się zapisać. Nie można być nimi.

Gdyby zechcieli porozmawiać, można by się domyślić

Czym jest ból, choć oni mogliby cię opluć.

I dalej:

Prawdę znają tylko ofiary prawdy. Cała reszta to zdjęcia - film dokumentalny ${ }^{3}$.

Christopher Isherwood w szkicu A Berlin Diary, do którego - jak zauważa Piotr Sommer - nawiązuje wiersz Dunna, napisał znane zdanie: „Jestem aparatem fotograficznym $\mathrm{z}$ otwartą przesłoną, zupełnie biernym, rejestrującym, niemyślącym"' Z Z wierszem Dunna koresponduje także wiersz W.H. Audena Nie jestem aparatem fotograficznym:

Przyglądanie się przez soczewki być może jest pouczające,

ale za każdym razem winniśmy przepraszać

to, co dalekie albo znikome

za naruszenie ich jestestwa.

3 D. Dunn, Jestem kamerzysta, tłum. P. Sommer, [w:] Antologia nowej poezji brytyjskiej, wybór. P. Sommer, Warszawa 1983, s. 79.

4 „I am a camera with its shutters open, quite passive, recording, not thinking”; Ch. Isherwood, A Berlin Diary (1930), [cyt. za:] Antologia nowej poezji brytyjskiej, op. cit., s. 367. 
I dalej:

Sceny z Przeszłości kłamią o Przeszłości, zapominają pamiętającą Teraźniejszość ${ }^{5}$.

Kim była kobieta dźwigająca bezwładne dziecko? Jak miała na imię? Jaką historię zostawiła za sobą, za kurtyną dymu, która podzieliła jej życie, jej czas na „przed” i „po”? Dla widza - jest tylko mgnieniem, figurą czystej rozpaczy. Mdlącym zdziwieniem, że to, co w strzępach zwisa z nóżek dziecka, to nie podarte rajstopy, to skóra.

\section{8.}

„Choćby sfotografowana postać była już całkowicie zapomniana, a jej imię wymazane z ludzkiej pamięci - a może raczej właśnie dlatego - ta osoba, ta twarz domaga się imienia, domaga się, byśmy o niej nie zapomnieli"6 pisał Giorgio Agamben.

Pierwsze zdjęcie - niczego nie ułatwia, z niczego nie zwalnia, nie daje się uciszyć. Już nawet nie trzeba na nie patrzeć - po prostu jest, wrasta w oczy, zamieszkuje pod powiekami jak mapa szarych plam. Już nawet nie trzeba pamiętać - ono pamięta się samo, tak jak sama pamięta się melodia wiersza, kiedy wylecą z pamięci słowa.

Ta niechciana, nieproszona pamięć pierwszego zdjęcia jest trochę jak optyczny obraz następczy - tyle że prawdziwy powidok to świat w kolorach dopełniających, odwróconych. Więc może to jakiś powidok fotograficzny negatyw zamiast pozytywu? Nie, to raczej obraz, który odwraca znaczenia. Najlepiej, najostrzej pamięta się miejsca najmniej obciążone: $\mathrm{z}$ fotograficzną dokładnością widać na dnie oka kępę ostów, pojedyncze dziewanny, kontur grupy ludzi, zarysy drzew, białą dłoń jednej z kobiet, czarny nos psa. Można by ich odrysować „spod powiek”, opisać z pamięci, licząc na to, że przepisani, przełożeni na ludzki język dadzą się wreszcie sprowadzić na miejsce - na papier zdjęcia. Są chętni do odwrotu - ci ludzie, te dziewanny, ta łąka i kudłaty pies, gotowi odejść spod powiek, zejść z oczu, odfrunąć motylim lotem na papierową łąkę.

5 W.H. Auden, Nie jestem aparatem fotograficznym, tłum. J. Rostworowski, „Literatura na Świecie” 1976, nr 11.

${ }^{6}$ G. Agamben, Profanacje, tłum. M. Kwaterko, Warszawa 2006, s. 38. 
Środek kadru, ona, jej gest, jej twarz - to obraz zupełnie inny: postrzępiony, niespójny, miejscami przezroczysty. Najmniej wyraźny, ale najbardziej uparty, wrośnięty, nieskłonny do pertraktacji.

Więc jeszcze kilka powrotów do zdjęcia. Po co? Żeby dała się oswoić? Nazwać? Żeby sobie poszła? Żeby móc patrzeć na zdjęcie bez ucieczek, bez dreptania po łące za plecami tych siedmiorga, bez udawania, że środek kadru jest pusty?

Oswoić się z jej bliskością, zbadać wzrokiem ciasny kadr wokół niej. Wgniecenie w fakturze łąki, tło za jej głową, wzorek na spódnicy kobiety stojącej z tyłu. Bliżej: kilka warstw ubrania, podwinięty rękaw. Jeszcze bliżej: chustka na głowie, kosmyk włosów. Jeszcze: zadrapanie na policzku, rysunek wygiętych brwi, usta, jakby nie mogła przełknąć powietrza. I już: jej oczy, wzrok, spojrzenie.

„Niemożliwe jest choćby wyobrażenie sobie własnej śmierci - pisał Elias Canetti - Wydaje się nierzeczywista. Jest najbardziej nierzeczywistą rzeczą pod słońcem"”.

Jej spojrzenie: ona wierzy w śmierć.

Jej wiara - zaraża.

\section{9.}

Pod październikowym słońcem tego zdjęcia śmierć nie jest nierzeczywista. Pod tym słońcem - śmierć to nic nowego. Nic nowego dla wiedzy, ale nie dla wiary - każdy wie, nikt nie wierzy. Ona - wydaje się, że tak. Ten ułamek sekundy, migawka zdjęcia, uchwyciły spojrzenie, które patrzy w śmierć. To jej własna śmierć, jej osobista śmierć, śmierć tylko dla niej - śmierć jej twarzy, jej zadrapanego policzka, jej kosmyka włosów spod chustki, śmierć jej ust, jej lewej ręki dotykającej ziemi, zsuwającej się pod ziemię. Śmierć, przeciwko której zbiera wszystkie drobinki rozsypującego się życia, cały wysiłek osłabłego ciała, całą odwagę upartego spojrzenia. Jej własna śmierć to rzeczywistość, realność tego zdjęcia.

${ }^{7}$ E. Canetti, Tajemne serce zegara, tłum. M. Przybyłowska, Sejny 2007, s. 72. 


\section{0.}

Z perspektywy widza przestrzeń szokującej nie-rzeczywistości tego obrazu uderza spoza kadru, gra w Barthes'owskim „zakrytym polu”. Najbardziej nierzeczywisty na tym zdjęciu jest fotograf. Kim był ten niemiecki żołnierz? Amatorem $\mathrm{z}$ aparatem? Zawodowcem w mundurze? ${ }^{8}$ To zdjęcie różni się od wielu innych niemieckich zdjęć zrobionych po inwazji na Wschód - wśród widoków martwych koni, polowych kuchni, wykolejonych pociagów, ten starannie skomponowany kadr, ten obraz o fakturze bujnej łąki nie jest zwykłą migawką dokumentującą wyczyny niemieckiej armii. Dlaczego ją sfotografował, tę kobietę osuwającą się na trawę? Czy jej gest wydał mu się poruszający? Zabawny? Chciał zostawić po niej ślad? Zobaczyć ją przez obiektyw, żeby choć przez chwilę to nie działo się naprawdę? Czego był świadomy, a czego nie? Kto wcisnął migawkę? Rozbawiony sadysta, który za chwilę odłoży aparat i sięgnie po pistolet? Ktoś, kto nie mógł dla niej nic zrobić, więc zrobił chociaż to? Niezależnie od intencji, zrobił wiele - zostawił jej twarz, jej obraz, ostatni, być może jedyny.

Po sobie (co się z nim stało, czy przeżył wojnę?) zostawił dwa ślady. Jeden to podpis na odwrocie zdjęcia: „Żydzi tuż przed rozstrzelaniem”. Poraża lodowata groza tego zdania, niepojęta nonszalancja tego „tuż przed”. Drugi ślad to jego spojrzenie, jego miejsce - to miejsce, w którym stał, w trawie po kolana, pod październikowym słońcem. Miejsce, z którego patrzył na to wszystko, na nią, na nich, na ich żółte łaty, na drzewa na horyzoncie. Miejsce, w którym została po nim wgnieciona w trawie niecka, kiedy już było „po wszystkim". Miejsce, z którego wtedy zrobił zdjęcie, i miejsce, z którego dzisiaj trzeba na nie patrzeć - $\mathrm{z}$ tej wydeptanej trawy, $\mathrm{z}$ wysokości jego oczu. Być może to także powód, dla którego patrzenie na zdjęcie, na nią, jest takie trudne. Powód, dla którego spojrzenie cofa się, więdnie, usycha. Bo ustawić się w miejscu fotografa, w tej trawie, $w$ tej macierzance i lwich paszczach, to znaczy patrzeć wzdłuż linii jego oczu, to znaczy patrzeć oczyma, które najpierw precyzyjnie regulują ostrość przez wizjer aparatu, a potem powtarzają ten gest - ustawiając szczerbinkę i muszkę na lufie pistoletu.

To nie jest zdjęcie, z którym można eksperymentować, to nie jest zdjęcie, które można rozpakować, rozłożyć na elementy, otworzyć na grę wyobraźni.

8 „Należało ono do przypadkowego zbioru fotografii wykonanych przez żołnierzy" - pisze o zdjęciu Ian Jeffrey, op. cit., s. 250. 
To kadr, którego trzeba delikatnie dotykać, ostrożnie używać słów, jeśli już jakieś uda się znaleźć. Ale być może warto zapytać, czy i jak zmieniałby się odbiór zdjęcia, gdyby historia tych ośmiorga, jej historia, miała inne zakończenie? Gdyby nie było podpisu, gdyby nie to niepojęte, niepojmowalne „tuż przed”?

\section{1.}

Tymczasem, kilka kadrów później: łąka po nich - otworzyła się, zamknęła. Trochę zamieszania na powierzchni, przegrupowania w kępach traw. Luki i szczeliny szybko ceruje perz - nieustraszony i wszędobylski, błyskawicznie uzupełnia straty, splata porwane korzenie. Zaraz potem: dziewanny - odzyskują wyrwane przyczółki, lwie paszcze - okopują się na dawnych pozycjach, wrasta w ziemię połamany oset, wierzchem pełznie macierzanka.

Dzień po nich: słońce pada pod tym samym kątem.

Dzień po nich: „Ładny dzień, żadnych wspomnień” Wallace’a Stevensa:

Dzisiaj powietrze jest idealnie puste.

Nie ma w nim żadnej wiedzy poza pustką,

Płynie ponad nami pozbawione znaczeń,

Jakby nikogo z nas nigdy tu nie było

I nie ma: w tym marnym spektaklu,

W tej niewidzialnej aktywności, w tej formie ${ }^{9}$.

\section{2.}

„Fotografowanie - zauważa Susan Sontag - to w gruncie rzeczy akt nieinterwencji. [...] Osoba interweniująca w czasie wydarzenia, nie może go rejestrować, osoba rejestrująca nie może interweniować"10.

Jeśli by przeformułować spostrzeżenie Sontag, można zauważyć, że fotografia jest aktem nieinterwencji w innym znaczeniu - w najprostszym, najbardziej poruszającym doświadczeniu widza patrzącego na zdjęcie. Nie można włożyć ręki w kadr, nie można zagarnąć na dłoń, jednym gestem

9 W. Stevens, Ładny dzień, żadnych wspomnień, [w:] idem, Żółte popołudnie, tłum. J. Gutorow, Wrocław 2008, s. 95.

10 S. Sontag, O fotografii, tłum. S. Magala, Warszawa 1986, s. 16. 
Guliwera, tych ośmiorga, razem z ich kudłatym psem, zabrać ich stamtąd „tuż przed”.

Przyglądanie się zdjęciom to splątanie iluzji. Perspektywa fotografa - jego „tu” $i$ „nie-tu”, bycie wewnątrz sytuacji i jednocześnie na zewnątrz - zostawia margines wolności, margines wyboru. Można zrobić wiele, można zrobić mniej, jeszcze mniej, lub nie zrobić nic. Perspektywa widza patrzącego na zdjęcie to bezgłos - nie móc nic zrobić, nie mieć wyboru.

Film nie ma własnych słów.

Jest milczącym rumowiskiem rzeczy wydarzających się

Bez nas, kiedy za późno na pomoc

- pisał Douglas Dunn ${ }^{11}$. Być skazanym na patrzenie, być skazanym na użyczenie miejsca w pamięci. Perspektywa obserwatora zza grubej szyby, perspektywa nurka spuszczającego się w bezpiecznym kombinezonie w obcy, podwodny świat - to zawsze los widza; czasem: wybór fotografa.

\section{3.}

Patrzeć na zdjęcia sfotografowanych w ostatniej chwili, na ludzi „tuż przed”, „tuż po", na granicy - to trochę jak towarzyszyć komuś w umieraniu. Tylko że prawdziwe umieranie, czyjeś umieranie, kiedyś się kończy, potem trzeba wyjść, odetchnąć żywym powietrzem, posklejać pamięć, żyć. Fotograficzne „tuż przed” rozciąga się na lata, rozkłada się na spojrzenia, staje się wciąż i wciąż, nigdy się nie kończy, dopóki trwa zdjęcie. Nie jest procesem, nie jest przeżyciem, jest powtarzającą się jednokrotnością, zatrzymaniem poruszającym się w czasie, niepojętym paradoksem, złym snem.

Susan Sontag tak pisze o zdjęciach z Bergen-Belsen i Dachau, które zobaczyła jako dwunastoletnia dziewczynka: „Były to tylko zdjęcia z wydarzenia, o którym ledwo słyszałam i na które nie miałam żadnego wpływu, nie mogłam mu zapobiec. Gdy patrzyłam na nie, coś się we mnie załamało. Dotarłam do jakiejś granicy, nie tylko granicy potworności: czułam nieodwracalny smutek, przygnębienie, ale zarazem coś we mnie stwardniało, coś obumarło, coś jeszcze płacze”. I dalej: „Sądzę nawet, że mogłabym

11 D. Dunn, op. cit., s. 79. 
podzielić moje życie na dwie części: zanim zobaczyłam te zdjęcia [...] i po ich ujrzeniu"12.

\section{4.}

Coś jeszcze płacze - i nie chce przestać. Obrazy na zdjęciach - nie chcą odejść.

To się nie dzieje naprawdę - wiadomo. To się w ogóle nie dzieje - to też wiadomo. Ale pamięć nie jest logiczna, są kadry, których nie da się usunąć spod powiek, mimo że (dlatego że) tak trudno na nie patrzeć. Są zdjęcia, które wbrew logice wydarzeń (to było dawno, to już się stało), wbrew logice w ogóle (to tylko zdjęcie, to tylko papier) czegoś się domagają, czegoś chcą.

„Wymóg, jaki stawia nam każda fotografia: ukazując rzeczywistość pogrążającą się w niebycie, żąda, aby przywrócić jej aktualność"13 - pisał Agamben.

Zdjęcia, które nie chcą odejść: każdy ma własny, prywatny zestaw kadrów, własny pokaz slajdów - w zamkniętych oczach.

Czego chce zdjęcie Reginy Fisz? Jak można na nie patrzeć? Wśród innych zdjęć ofiar pogromu kieleckiego, wśród obrazów plątaniny rąk i nóg, rozchlastanych brzuchów, posiniaczonych twarzy - to zdjęcie, w pewnym sensie najmniej drastyczne, rani najbardziej.

Młoda kobieta zamordowana z kilkutygodniowym synkiem, zakopana, po kilku dniach ekshumowana. Leży na podłodze, na czarno-białej posadzce w skośną szachownicę. Ręce na piersiach, zamknięte oczy, rozpuszczone czarne włosy, delikatna twarz, bez śladu śmierci. Regina Fisz śpi. Do brzucha przytulone niemowlę. Jeśli spojrzeć inaczej, zamienić poziom kadru na pion, ciało Reginy, jej zastygłe gesty, fałdy tkaniny, które wyglądają jak starannie udrapowane - wszystko to przypomina jedno z malarskich przedstawień Madonny. Regina Fisz - nie można patrzeć na jej zdjęcie, nie słysząc tego: „Doszedłem do szofera i powiedziałem mu, że mamy Żydów i chcemy ich wywieźć, aby ich zabić. Szofer zgodził się na to i tylko domagał się wynagrodzenia w kwocie tysiąca złotych, a ja powiedziałem, że »zrobi się«"14.

12 S. Sontag, op. cit., s. 24.

13 G. Agamben, op. cit., s. 40.

14 J.T. Gross, Strach. Antysemityzm w Polsce tuż po wojnie. Historia moralnej zapaści, Kraków 2008, s. 162. 
Czego chce zdjęcie małej Anny Frank? Wcale nie straszne, nie okrutne, nie „tuż przed”, nawet nie to wojenne z 1941 roku, ale wcześniejsze - z siostrą imieniem Margot. Zwykłe zdjęcie z dzieciństwa: „Anne, Margot i pokojówka Kathi” z 1929 roku. Nie da się na nie patrzeć, nie myśląc o zbiorowych grobach w Bergen-Belsen, do których wrzucono oba ciała, Anny i Margot, razem $z$ innymi ofiarami epidemii tyfusu, na miesiąc przed wyzwoleniem obozu. Jak patrzeć na jej zdjęcia, jak patrzeć na dwudziestosekundowy film dokumentalny, jedyny, na którym przez moment widać jej twarz, nie myśląc o tym, co piętnastoletnia Anna napisała w swoim dzienniku na dziesięć dni przed aresztowaniem: „To wielki cud, że nie zrezygnowałam ze wszystkich swoich oczekiwań, bo wydają się absurdalne i niewykonalne. Mocno się ich jednak trzymam, mimo wszystko, ponieważ stale jeszcze wierzę w wewnętrzną dobroć ludzi"15.

Czego chcą zdjęcia z Auschwitz, o których pisze Georges Didi-Hubermann, cztery zdjęcia zrobione przez Alexa, węgierskiego Żyda o nieznanym nazwisku. Chaotyczne, niewykadrowane, pstryknięte aparatem przemyconym na teren obozu w podwójnym dnie kotła z zupą, na kawałku kliszy wyniesionym później na zewnątrz w tubce pasty do zębów ${ }^{16}$.

Te zdjęcia: dwa zrobione $z$ wnętrza komory gazowej, tuż po jej opróżnieniu, i dwa aparatem ukrytym w dłoni lub pod ubraniem. Dwa pierwsze: palenie zwłok, i to zdanie: „Po oczyszczeniu dołów resztki szybko przewożono w taczkach do składu popiołów i usypywano z nich stosy wysokości człowieka"17. Dwa kolejne: nagie kobiety tuż przed wejściem do komory gazowej, i zdanie: „Najstraszniejszą chwilą było otwarcie komory gazowej. Widok nie do zniesienia: ludzie sprasowani jak bazalt, zbite bloki kamienia"18. Czego chcą te cztery zdjęcia, nad którymi nawet nie da się płakać, o których nic nie da się powiedzieć poza zapisaniem lodowatego zdumienia, absurdalnego banału - to tam rosły drzewa? Było lato? To możliwe?

Czego chce Didi-Huberman, kiedy pisze:

15 A. Frank, Dziennik, tłum. A. Dehue-Oczko, Poznań 1993, s. 255.

${ }_{16}$ G. Didi-Huberman, Obrazy mimo wszystko, tłum. M. Kubiak Ho-Chi, Kraków 2008, s. 18-21.

17 Ibidem, s. 18.

18 Filip Müller, przytoczone przez C. Lanzmanna, [cyt. za:] G. Didi-Huberman, op. cit., s. 50. 
Aby wiedzieć, trzeba sobie wyobrazić. [...] Nie odwołujmy się do niewyobrażalnego. Nie brońmy się, mówiąc - co zresztą jest prawdą - że nie jesteśmy i nigdy nie będziemy w stanie pojąć tego wszystkiego. Ale musimy, musimy wyobrazić sobie tę jakże trudną wyobrażalność. Jako odpowiedź do udzielenia, jako dług wobec słów i obrazów, wyrwanych dla nas przez kilku zesłańców z przerażającej rzeczywistości ich doświadczeń. Nie odwołujmy się więc do niewyobrażalnego. O ile trudniej było owym więźniom wykraść z obozów te strzępy, które teraz przechowujemy, utrzymując z trudem ich ciężar jednym spojrzeniem ${ }^{19}$.

Czy o to chodzi zdjęciom? O to chodzi Agambenowi, kiedy pisze: „ta osoba, ta twarz domaga się imienia"? Trzeba wyobrazić sobie - stanąć na ich miejscu? Być tam? Na łące pod Kijowem? W dymie, na autostradzie do Kambodży? Na posadzce w skośną szachownicę na posterunku w Kielcach? We Frankfurcie, na tarasie domu Franków, spojrzeć w oczy tych małych dziewczynek? W Auschwitz? Zdjąć ubranie przed wejściem do komory gazowej? Stanąć nad dołem spaleniskowym, w którym żarzą się zwłoki, topią włosy, pęka skóra? Przez moment nosić, dźwigać ich imiona? Użyczyć im własnych? Dotknąć wyobraźnią czegoś, przed czym bronią się wszystkie zmysły, całe ciało?

„Musimy, musimy wyobrazić sobie tę jakże trudną wyobrażalność”.

Zamknąć oczy, nie mieć wyobraźni.

\section{5.}

„Zdjęcia stanowią świadectwo niezliczonych imion popadłych w zapomnienie” - pisał Agamben. „Można je porównać do księgi życia, którą nowy anioł apokalipsy - anioł fotografii - trzyma w rękach w dniu ostatnim, a więc codziennie" 20 .

Kto to jest? - pytamy, oglądając stare zdjęcia.

„Czyja to twarz" - pisał Ficowski w Dedykacji:

Trzeba nam jak najprędzej

przedstawić się czasom

aby było wiadomo

19 G. Didi-Huberman, op. cit., s. 9.

20 G. Agamben, op. cit., s. 40. 
po jakim imieniu

byliśmy ze sobą ${ }^{21}$.

Zdjęcia podpisane i niepodpisane - ta różnica ma duże znaczenie w fotografii prywatnej, w rodzinnej tradycji, w scalaniu zbiorowej pamięci. Rytuał podpisywania zdjęć jest gestem przekazania depozytu pamięci, wypełnieniem zobowiązania wobec zmarłych. Maria Iwaszkiewicz w książce $Z p a-$ mięci pisze o tym rytuale, wspominając rodzinny album: „W ostatnich latach przed śmiercią Ojciec powpisywał nazwiska fotografowanych osób. Ja już nie umiałabym powiedzieć, kogo przedstawiają, ponieważ portretowane osoby żyły przeważnie na przełomie wieku dziewiętnastego i dwudziestego"22.

W Agambenowskim wymogu utrzymywania przy życiu oddalającej się przeszłości („ta osoba, ta twarz domaga się imienia, domaga się, byśmy o niej nie zapomnieli”23) imię to metafora, to coś, co przetrwa dłużej niż ciało. Imię to pamięć, to naznaczenie spojrzeniem, które stwarza, które jak pisał Agamben - przywraca aktualność rzeczywistości pogrążającej się w niebycie.

Czy to ważne, jakie imię nosiła kobieta z pierwszego zdjęcia? Bardzo ważne - z punktu widzenia osobistej, prywatnej pamięci. Bardzo ważne z perspektywy żydowskiej tradycji, w której utrwalenie i pamięć imienia zmarłego jest religijnym nakazem. Ale wymóg pamięci, o którym pisze Agamben, nie ma wiele wspólnego z tym, jak miała na imię kobieta z pierwszego zdjęcia. Które to imię spośród imion półtora miliona Żydów zamordowanych na Ukrainie w czasie II wojny? Które imię spośród imion wrzuconych do dwóch tysięcy zbiorowych grobów? Jak miała na imię? Chaja, Estera, Gołda? Rojza, Małka, Sara?

Czy znajomość jej imienia sprawiłaby, że pamięć o niej byłaby łatwiejsza, pełniejsza? Czy poczucie zobowiązania wobec niej, wobec jej spojrzenia, nie jest silniejsze, bardziej osobiste właśnie dlatego, że jest tak pozbawiona wszystkiego, pozbawiona imienia, tak bezbronna?

Agamben wspomina o „niewątpliwie pretensjonalnej” dedykacji, którą Edgar Aubert napisał na odwrocie swojego zdjęcia podarowanego Proustowi. Dedykacja jest cytatem z sonetu Dantego Gabriela Rossettiego

${ }^{21}$ J. Ficowski, Dedykacja, [w:] idem, Gorączka rzeczy, Warszawa 2002.

22 M. Iwaszkiewicz, $Z$ pamięci, Warszawa 2006, s. 257.

23 G. Agamben, op. cit., s. 40. 
A Superscription: „Spójrz na moją twarz: nazywam się Mógłbym Być; wołają mnie także Nigdy Więcej, Za późno, Żegnaj”"

Imiona wszystkich bezimiennych.

\section{6.}

Imię umarłego. Jego twarz, jego historia, pamięć o nim.

„Dopóki nie znam jego imienia, być może potrafię go jeszcze zapomnieć, czas zatrze ów obraz. Lecz imię jego jest gwoździem, który wbije się we mnie i którego nie zdołam już wydobyć. Posiada moc wywoływania wszystkiego na nowo, zawsze będzie mógł powracać i stawać przede mną"25 - mówi Paweł, bohater Na Zachodzie bez zmian Ericha Marii Remarque’a, kiedy nad ciałem francuskiego żołnierza waha się, czy zajrzeć do jego dokumentów, zastanawia się, czy chce poznać jego imię. Paweł, wysłany na nocny patrol, utknął w leju po bombie, unieruchomiony gęstym ogniem kulomiotów. Kiedy w zagłębienie leja ześlizgnął się obcy żołnierz, Paweł bez wahania zakłuł go nożem. Sytuacja zmusiła go do towarzyszenia umierającemu. Od odruchu: „zatkać mu usta, napchać w nie ziemi, jeszcze raz go przebić", do spojrzenia w oczy: „oczy krzyczą, wyją, w nich skupione jest całe życie, wysiłek nie do objęcia, aby uciec w przeraźliwą trwogę śmierci, w trwogę przede mną"26. Od gotowości, żeby rzucić się z nożem na rannego, ,jeśli się poruszy", do napojenia go wodą z dna leja i założenia opatrunków. Paweł patrzy na umieranie, którego jest przyczyną, którego jest sprawcą. „,To pierwszy człowiek, którego zabiłem własnymi rękami, którego dokładnie mogę oglądać, którego umieranie moim jest dziełem" ${ }^{27}$. Kiedy ranny umiera, Paweł sięga po jego książeczkę wojskową - sięga, a następnie cofa się. Pugilares zmarłego wysuwa mu się z rąk, wypadają listy i zdjęcia: „Są to fotografie jakiejś kobiety i małej dziewczynki, wąskie amatorskie zdjęcia przed ścianą oplecioną bluszczem"28. Paweł ratuje się myślą o przesłaniu pieniędzy wdowie i dziecku: „I dlatego otwieram książeczkę wojskową i czytam powoli:

${ }^{24}$ Ibidem.

25 E.M. Remarque, Na Zachodzie bez zmian, tłum. S. Napierski, Katowice 1956, s. 155.

26 Ibidem, s. 151.

27 Ibidem, s. 152.

28 Ibidem, s. 155. 
Gerard Duval, zecer. Ołówkiem zmarłego zapisuję adres na przypadkowej kopercie, a potem ostro i szybko wsuwam wszystko z powrotem do jego kurtki. Zabiłem zecera Gerarda Duvala. Muszę zostać zecerem, myślę w zupełnym zamęcie, zostać zecerem, zecerem"29.

Paweł gra z pamięcią na granicy ryzyka - poznać jego imię? Wejść głębiej w krąg, który łączy, który zawsze będzie łączył ich obu? Czy wycofać się, obejść zmarłego na palcach? Jeżeli Paweł nie dowie się teraz, nie dowie się już nigdy.

„Ten umarły jest związany z moim życiem, dlatego muszę uczynić wszystko i wszystko obiecać, aby ocalić siebie"30. Umarły jest zagrożeniem. W ambiwalencji uczuć Pawła, w sposobie, w jaki mówi o francuskim żołnierzu, słychać dalekie echo zakazów i nakazów związanych z tabu względem zmarłych, o którym pisał Freud: „Jednym z najdziwniejszych, ale zarazem najbardziej pouczających zwyczajów tabu związanych z żałobą, jakie spotykamy u ludów pierwotnych, jest zakaz wymawiania imienia zmarłego. Wydaje się im, że wymienienie jego imienia to jakby zaklęcie, mocą którego zmarły musi się natychmiast zjawić"31. Paweł tego chce i nie chce jednocześnie. A może chce nazwać, żeby zapomnieć? Żeby odesłać Gerarda Duvala do albumu wojennych wspomnień, nadać mu formę i właściwą miarę, żeby nie rozrósł się w jakiś amorficzny twór z własną autonomią, atakujący pamięć znienacka, odbierający możliwość obrony.

Nadać imię, opisać, sfotografować - odesłać do archiwum.

Może rację miał Franz Kafka, kiedy twierdził, że „fotografuje się rzeczy, żeby usunąć je $z$ umysłu”? Że jego opowieści są „w pewnym sensie zamykaniem oczu"? ?2

Wydaje się, że Paweł zapomina szybko i świadomie rejestruje ten proces: „Nie myślę już o umarłym, obecnie jest mi całkiem obojętny”.

Uspokaja się, wypowiadając własne imię: „Teraz bez głupstw, Pawełku... spokój, spokój, Pawle... wtedy będziesz uratowany, mój drogi. To skutkuje,

29 Ibidem, s. 155-156.

30 Ibidem, s. 155.

${ }^{31}$ S. Freud, Totem i tabu, tłum. M. Poręba, R. Reszke, [w:] idem, Pisma społeczne, Warszawa 1998, s. 41.

32 [Cyt. za:] R. Barthes, Światło obrazu. Uwagi o fotografii, tłum. J. Trznadel, Warszawa 1996, s. 96. 
kiedy wymawiam własne imię, jest to tak, jakby wypowiadał je kto inny, i to mi pomaga opanować się"33.

\section{7.}

Paweł uspokaja się jeszcze inaczej:

Umarły ten mógłby z pewnością żyć jeszcze trzydzieści lat, gdybym odwrót dokładniej sobie wytyczył. Gdyby pobiegł był o dwa metry bardziej na lewo, tkwiłby teraz w okopie po tamtej stronie i pisałby nowy list do swojej żony. Ale w ten sposób nie zdołam ruszyć się z miejsca; jest to bowiem los nas wszystkich; gdyby Kemmerich nogę trzymał dziesięć centymetrów bardziej na prawo; gdyby Haie pochylił się o pięć centymetrów niżej3 ${ }^{34}$.

Co to jest? Pół metra w lewo, dwa kroki w prawo? Wyżej, niżej? Bliżej, dalej?

Ludzie sfotografowani na granicy, na skraju - ze śladem sennego koszmaru na twarzy, ze śladem czegoś wymykającego się słowom, codziennego i niewyobrażalnego, pospolitego i wzniosłego, czegoś jak Zjadliwy Wirus ze Świata wedlug Garpa Johna Irvinga - zagrożenia, które przychodzi nagle, zjawia się w tej szczelinie miedzy kruchą stabilnością a nieprzewidywalnym, w „zdradliwym wirze”, który dla małego Walta Garpa był „Zjadliwym Wirusem".

Garp usiłował wyobrazić go sobie razem z Waltem. Czy kiedykolwiek wypływa na powierzchnię? Czy zawsze siedzi pod wodą, oślizły i nadęty, jak wielka ropucha, zawsze czujny, wypatrujący nóg, za które mógłby złapać swoim obłożonym jęzorem? Nikczemny Zjadliwy Wirus. [...] Długo jeszcze po tym, jak sprawa potwora została Waltowi wyjaśniona (,Wystrzegaj się zdradliw ych wirów, głupku, a nie żaden Zjadliwy Wirus - ryknął Duncan), poczucie zagrożenia jawiło się Garpowi i Helen jako potwór ${ }^{35}$.

Już po śmierci małego Walta Duncan przypomniał Helen i Garpowi, jak chłopczyk pytał, czy Zjadliwy Wirus jest zielony, czy brązowy. „Obaj,

33 E.M. Remarque, op. cit., s. 157.

34 Ibidem, s. 153-154.

35 J. Irving, Świat według Garpa, tłum. Z. Uhrynowska-Hanasz, Warszawa 1984, s. 363. 
i Garp, i Duncan, się roześmieli. Ale nie był ani zielony, ani brązowy - pomyślał Garp. Był mną. I Helen. Miał kolor paskudnej pogody. A wielkość samochodu"36.

Zjadliwy Wirus, Benjaminowski garbusek, przypadek, konieczność. Czasem ma twarz pilota, który przez pomyłkę zrzucił bomby z napalmem, czasem twarz fotografa. Dla Reginy Fisz miał twarz sąsiadów, dla Anny Frank mundur Grüne Polizei. Gerard Duval spotkał go w leju po bombie. Dla Franusia Kemmericha miał głos bzyczącej kuli, do szeregowca Telli z Cienkiej czerwonej linii - zastukał warkotem cekaemu. Czym, kim był dla kobiety z pierwszego zdjęcia - nawet tego o niej nie wiadomo.

A reszta? A wszyscy inni? Ile razy udało się wymknąć?

Jeszcze raz Remarque:

Niekiedy kładziemy karty i spoglądamy na siebie. Któryś z nas powiada: „No, chłopcy” albo: „To się mogło źle skończyć” i na chwilę milkniemy.

Jest to w nas mocne, utajone uczucie, każdy je wyczuwa, nie trzeba mu wielu słów. Łatwo mogło się wydarzyć, a nie siedzielibyśmy dzisiaj na naszych skrzyniach, diabelnie blisko byliśmy tej możliwości.

I dlatego wszystko jest nowe i silne - czerwone maki i dobre jedzenie, papierosy i letni wiatr ${ }^{37}$.

36 Ibidem, s. 363.

37 E.M. Remarque, op. cit., s. 13. 